\title{
UPAYA PENINGKATAN KUALITAS BIJI KAKAO (Theobroma Cacao L.) MELALUI TAHAP PENANGANAN PASCAPANEN (ULASAN)
}

\author{
Efforts to Improve Cocoa Bean Quality (Theobroma Cacao L.) through the Postharvest \\ Handling Stage (Review) \\ Sri Hartuti ${ }^{1}$, Juanda ${ }^{2}$, dan Rita Khathir ${ }^{1}$ \\ ${ }^{1}$ Program Studi Teknik Pertanian, Universitas Syiah Kuala. Jl. Tgk. Hasan Krueng Kalee, No. 3 \\ Kopelma Darussalam - Banda Aceh 23111, Indonesia. \\ ${ }^{2}$ Program Studi Teknologi Hasil Pertanian, Universitas Syiah Kuala. Jl. Tgk. Hasan Krueng \\ Kalee, No. 3 Kopelma Darussalam - Banda Aceh 23111, Indonesia. \\ e-mail: juanda@unsyiah.ac.id
}

\begin{abstract}
Cocoa beans postharvest handling is an important step to improve bean quality to meet the applicable standard and consumer demand. This review aims to identify stages of postharvest handling that affect the quality improvement of cocoa beans. Ripening of cocoa pods, fermentation, and drying of beans significantly affect the quality of beans, especially in the formation of their characteristic precursors for taste and appearance. Ripening aims to reduce the pulp layer and form an empty space in bean piles so that oxygen can enter piles during fermentation, accelerate the process, reduce moisture, polyphenols, and acidity. Fermentation aims to produce candidate compounds that form the chocolate distinctive flavor and affect bean quality and appearance. The length of the process is generally 5-7 days, influenced by cocoa types and various factors like method, temperature, and the number of beans. Furthermore, drying aims to reduce moisture content by $\leq 7.5 \%$, form flavor, and determine the quality characteristics of beans. Increasing drying temperature will increase the chelating and sour taste so the temperature should be $<70^{\circ} \mathrm{C}$. Finally, to improve the cocoa beans quality and value, implementation of MOA No. 51 of 2012 on cocoa post-harvest handling guidelines still needs to be pursued more intensively.
\end{abstract}

Keywords: postharvest, ripening, fermentation, drying, cocoa beans quality

\begin{abstract}
Abstrak: Penanganan pascapanen biji kakao merupakan tahapan penting untuk meningkatkan kualitas biji kakao agar memenuhi standar yang berlaku sehingga dapat memenuhi permintaan konsumen. Ulasan ini bertujuan untuk mengidentifikasi tahapan-tahapan penanganan pascapanen yang memiliki pengaruh terhadap peningkatan kualitas biji kakao. Proses pemeraman buah, fermentasi, dan pengeringan biji kakao memiliki pengaruh penting terhadap kualitas biji, terutama dalam pembentukan karakteristik prekursor rasa dan tampilan biji. Pemeraman buah bertujuan untuk mengurangi lapisan pulp dan membentuk ruang kosong dalam tumpukan biji, sehingga oksigen dapat masuk ke dalam tumpukan biji selama fermentasi, mempercepat proses fermentasi, menurunkan kadar air, polifenol, dan keasaman. Fermentasi biji bertujuan untuk menghasilkan senyawa-senyawa calon pembentuk citarasa khas cokelat serta mempengaruhi kualitas dan penampilan biji. Lama proses fermentasi dilakukan selama 57 hari, yang dipengaruhi oleh jenis kakao dan berbagai faktor lainnya seperti metode, suhu, serta jumlah biji yang difermentasi. Selanjutnya, proses pengeringan bertujuan untuk menurunkan kadar air hingga $\leq 7,5 \%$, membentuk citarasa, dan menentukan karakteristik kualitas biji kakao. Peningkatan suhu pengeringan akan meningkatkan rasa kelat dan asam sehingga suhu pengeringan sebaiknya $<70^{\circ} \mathrm{C}$. Akhirnya, untuk meningkatkan kualitas dan nilai jual biji kakao, implementasi Permentan No. 51 tahun 2012 tentang pedoman penanganan pascapanen kakao masih perlu diupayakan secara lebih intensif.
\end{abstract}

Kata kunci: pascapanen, pemeraman, fermentasi, pengeringan, kualitas biji kakao 


\section{PENDAHULUAN}

Kakao (Theobroma cacao L.) merupakan salah satu komoditas perkebunan di Indonesia yang memiliki peranan penting bagi perekonomian nasional untuk peningkatan devisa negara. Namun demikian, mutu kakao Indonesia khususnya produksi biji kakao perkebunan rakyat masih rendah (Manalu, 2018). Sebagaimana diketahui bahwa sebagian besar kakao Indonesia dihasilkan dari perkebunan rakyat di berbagai wilayah Indonesia, dengan pemahaman petani kakao yang beragam dan cenderung kurang memahami tata cara penanganan kakao secara baik, terutama pada tahap penanganan pascapanen.

Saat ini, selain melakukan ekspor kakao yang tinggi, Indonesia juga mengalami peningkatan impor kakao yang cukup besar yaitu 84.438 ton pada tahun 2015 dan meningkat menjadi 289.002 ton pada tahun 2018 dengan jenis impor kakao terbesar adalah biji kakao terfermentasi (fermented) (Direktorat Jenderal Perkebunan Kementerian Pertanian, 2019). Hal ini menunjukkan bahwa meskipun jumlah produksi biji kakao Indonesia sangat tinggi, akan tetapi kebutuhan biji kakao fermentasi tidak terpenuhi. Sebagian besar produksi perkebunan kakao di Indonesia merupakan biji kakao yang belum difermentasi (unfermented) (Manalu, 2018). Beberapa alasan petani kakao Indonesia tidak melakukan proses fermentasi biji kakao yaitu: umumnya para petani kakao belum memahami cara penanganan pascapanen biji kakao (Sudjarmoko et al., 2017: Munarso, 2016), nilai jual biji kakao fermentasi dan non fermentasi hampir tidak ada bedanya (Hernani dan Haliza, 2013: Sumanto et al., 2015), dan diketahui bahwa selisih harga kakao non fermentasi dan kakao fermentasi hanya sekitar Rp3.000,Rp5.000 per kilogram (Manalu, 2018). Selain itu, proses fermentasi membutuhkan waktu dan tenaga lebih besar untuk mendapatkan penghasilan dari kebun kakao yang mereka usahakan (Manalu, 2018: Davit et al., 2013:
Widyastutik dan Arianti 2013: Listyati et al., 2014). Hal ini mengakibatkan kakao Indonesia memiliki mutu dan nilai jual rendah (Herawati et al., 2015). Padahal mutu kakao Indonesia dapat mencapai cita rasa setara dengan kakao yang berasal dari Ghana, jika difermentasi dengan baik. Selain itu, kakao Indonesia memiliki kelebihan tidak mudah meleleh (Siagian, 2017). Pantai Gading, Ghana, Indonesia, Nigeria, dan Kamerun adalah lima besar negara produsen dan pengekspor biji kakao di dunia. Kelima negara produsen kakao memiliki keunggulan komparatif di pasar internasional. Ghana merupakan negara dengan daya saing rata-rata tertinggi, diikuti Pantai Gading di posisi kedua, Kamerun ketiga, Nigeria keempat, lalu Indonesia kelima (Tresliyana et al., 2015). Oleh karena itu, tahapan penanganan pascapanen kakao harus dilakukan dengan baik, agar kualitas dan nilai jual kakao Indonesia dapat meningkat.

Tahapan

penanganan

pascapanen kakao secara umum dibedakan atas: pemeraman buah kakao, fermentasi, pengeringan, sortasi, pengemasan dan penggudangan. Penanganan pascapanen kakao yang baik dan benar diharapkan akan menghasilkan biji kakao yang berkualitas tinggi, sesuai standar mutu biji kakao yang berlaku yaitu standar SNI 23232008/Amandemen 1:2010 dan juga sesuai dengan permintaan konsumen, terutama untuk tujuan ekspor dan industri pengolahan kakao. Tulisan ini diharapkan dapat memberikan informasi penting tentang tujuan, manfaat dan tahapan penanganan pascapanen biji kakao yang memberikan pengaruh terhadap pembentukan dan peningkatan kualitas biji kakao

Artikel ini ditulis berdasarkan hasil kajian atau studi pustaka tentang berbagai tahapan dan pentingnya penanganan pascapanen biji kakao terhadap kualitas biji kakao secara menyeluruh. Metode penelitian meliputi pengambilan data sekunder dari berbagai literatur yang diperoleh secara offline dan online, review jurnal yang terkait dengan 
berbagai tahap penanganan pascapanen biji kakao dan selanjutnya dilakukan pembahasan tentang faktor-faktor yang mempengaruhi kualitas kakao pada berbagai tahapan proses pascapanen.

\section{STANDAR MUTU BIJI KAKAO INDONESIA (SNI \\ 2323:2008/AMANDEMEN 1-2010)}

Standar mutu ditentukan sebagai tolak ukur untuk pengawasan pengendalian mutu biji kakao yang dihasilkan. Setiap bagian biji kakao yang akan diekspor harus memenuhi persyaratan standar mutu tersebut yang diawasi oleh lembaga pengawasan terkait yang ditunjuk. Biji kakao fermentasi merupakan salah satu prasyarat yang ditentukan sebagai standar mutu biji kakao Indonesia yang tercantum di dalam SNI 2323-2008/Amandemen 1:2010, dan telah ditindaklanjuti dengan Peraturan Menteri Pertanian Nomor 51/Permentan/OT.140/9/2012 (BPS, 2019: Davit et al., 2013). Upaya ini bertujuan untuk meningkatkan dan mempertahankan mutu biji kakao; mampu mengangkat kakao nasional agar dapat bersaing di pasar domestik maupun global; serta berkontribusi dalam mendukung pertumbuhan ekonomi nasional (Permentan No. 51, 2012). Untuk menghasilkan biji kakao yang berkualitas dan memiliki nilai ekonomi yang tinggi, tidak hanya tergantung pada varietas dan lingkungan pertumbuhan tanaman kakao saja, penerapan dan penanganan pascapanen kakao harus dilakukan dengan baik, supaya kakao yang dihasilkan memiliki kualitas yang baik pula.

Klasifikasi atau penggolongan mutu biji kakao kering di dalam SNI 012323-2008 terbagi menjadi tiga, yaitu menurut jenis tanaman, jenis mutu dan ukuran berat biji per 100 gram. Menurut jenis tanaman kakao, biji kakao digolongkan menjadi dua, yaitu biji mulia (biji kakao yang berasal dari tanaman kakao jenis Criollo atau Trinitario serta hasil persilangannya) dan biji kakao lindak (biji kakao yang berasal dari tanaman kakao jenis Forastero). Menurut jenis mutunya, biji kakao digolongkan dalam tiga jenis mutu, yaitu: mutu I, mutu II, dan mutu III. Standar mutu biji kakao diatur dalam SNI 2323:2008/Amandemen 1:2010, yang dikelompokkan ke dalam 5 (lima) kriteria ukuran yaitu:

- Mutu AA : jumlah biji maksimum 85 per 100 gram

- Mutu A : jumlah biji 86-100 per 100 gram

- Mutu B : jumlah biji 101-110 per 100 gram

- Mutu C : jumlah biji 111-120 per 100 gram

- Mutu S : lebih besar dari 120 biji per 100 gram

Tabel 1. Persyaratan Mutu Biji Kakao

\begin{tabular}{rlcl}
\hline No. & \multicolumn{1}{c}{ Jenis Uji } & Satuan & \multicolumn{1}{c}{ Persyaratan } \\
\hline 1 & Serangga hidup & - & Tidak ada \\
2 & Kadar air & $\%$ & Maks. 7,5 \\
3 & Berbau asap dan atau hammy dan atau & - & Tidak ada \\
4 & berbau asing & $\%$ & Tidak ada \\
5 & Kadar benda asing & $\%$ & Maks 2 \\
\hline
\end{tabular}

Sumber: SNI 2323:2008/Amandemen 1:2010 
Tabel 2. Persyaratan Mutu (Syarat Khusus)

\begin{tabular}{|c|c|c|c|c|c|c|}
\hline \multicolumn{2}{|c|}{ Jenis Mutu } & \multicolumn{5}{|c|}{ Persyaratan } \\
\hline $\begin{array}{c}\text { Kakao } \\
\text { Mulia } \\
\text { Fine Cocoa }\end{array}$ & $\begin{array}{c}\text { Kakao } \\
\text { Lindak } \\
\text { Bulk Cocoa }\end{array}$ & $\begin{array}{c}\text { Kadar Biji } \\
\text { Berjamur } \\
\text { (biji/ biji) } \\
(\%)\end{array}$ & $\begin{array}{l}\text { Kadar Biji } \\
\text { Slaty } \\
\text { (biji/ biji) } \\
(\%)\end{array}$ & $\begin{array}{c}\text { Kadar Biji } \\
\text { Berserangga } \\
\text { (biji/ biji) } \\
(\%)\end{array}$ & $\begin{array}{c}\text { Kadar } \\
\text { Kotoran/ } \\
\text { Waste } \\
\text { (biji/ biji) } \\
(\%)\end{array}$ & $\begin{array}{c}\text { Kadar Biji } \\
\text { Berkecam } \\
\text { bah } \\
\text { (biji/ biji) } \\
(\%)\end{array}$ \\
\hline $\begin{array}{c}I-F \\
(A A \text { s.d. S) } \\
\|-F\end{array}$ & $\begin{array}{c}I-B \\
(A A \text { s.d. S) } \\
I I-B\end{array}$ & Maks. 2 & Maks. 3 & Maks. 1 & Maks. 1,5 & Maks. 2 \\
\hline $\begin{array}{c}\text { (AA s.d. S) } \\
\text { III-F }\end{array}$ & $\begin{array}{c}\text { (AA s.d. S) } \\
\| I-B\end{array}$ & Maks. 4 & Maks. 8 & Maks. 2 & Maks. 2,0 & Maks. 3 \\
\hline (AA s.d. S) & (AA s.d. S) & Maks. 4 & Maks. 20 & Maks. 2 & Maks. 3,0 & Maks. 3 \\
\hline
\end{tabular}

Sumber: SNI 2323:2008/Amandemen 1:2010

Persyaratan mutu biji kakao lainnya dapat diketahui dari karakteristik fisik biji kakao, diantaranya: biji pipih, biji berjamur, biji berserangga, biji berkecambah, biji pecah, dan kadar kotoran (biji dempet, plasenta, pecahan biji dan kulit, dan benda lainnya), sebagaimana ditunjukkan pada Tabel 1 dan Tabel 2. Berdasarkan Tabel 1 dan Tabel 2, diketahui bahwa biji kakao harus memiliki kadar biji slaty maksimum $20 \%$ untuk mutu III, kadar biji slaty maksimum $8 \%$ untuk mutu II, dan kadar biji slaty maksimum 3\% untuk mutu I, yang diikuti dengan berbagai persyaratan lainnya yang tidak menunjukkan adanya perbedaan antara biji kakao fermentasi dan non fermentasi.

\section{TAHAPAN \\ PASCAPANEN KAKAO}

PENANGANAN

Panen adalah proses awal penentuan kualitas biji kakao. Buah kakao yang belum siap panen akan memberikan rendemen dan kualitas biji yang rendah. Sebaliknya, panen buah yang terlalu tua sebaiknya juga dihindari untuk mencegah biji mulai berkecambah serta menurunkan kualitas dan rendemen biji kakao (Permentan No. 51, 2012). Kematangan buah kakao ditandai dengan adanya perubahan warna kulit kakao mencapai dua pertiganya yaitu dari warna hijau atau merah (buah muda) menjadi kekuningan, kuning tua atau jingga (buah matang) dan apabila buah kakao digoyangkan, maka akan terdengar biji kakao terkoyak (Hatmi dan Rustijarno 2012). Biasanya, umur panen kakao sekitar 5 (lima) bulan, sejak fase pembuahan sampai menjadi buah dan matang (Departemen Perindustrian, 2007).

Penanganan pascapanen kakao merupakan rangkaian kegiatan setelah panen hingga diperoleh biji kakao kering yang siap diolah menjadi berbagai produk olahan cokelat, baik berupa bahan makanan dan minuman (Nurhayati et al., 2016). Pascapanen kakao adalah suatu kegiatan yang meliputi sortasi buah, pemeraman, pemecahan buah, pemerasan lender (pulp kakao), fermentasi, pencucian, pengeringan, pengemasan, dan penggudangan (Permentan No. 51, 2012). Penanganan pascapanen kakao berlangsung di negara penghasil kakao, dan merupakan faktor penentu terbentuknya flavour pada biji kakao kering (Krähmer et al., 2015). Alur proses panen dan penanganan pascapanen kakao secara garis besar dapat diperlihatkan pada Gambar 1 yang menunjukkan bahwa penanganan pascapanen kakao dibedakan atas: standar baku dan bukan standar baku. Standar baku dilakukan tanpa ada upaya melakukan pengurangan pulp biji kakao sebelum dan setelah proses fermentasi. Sementara pada tahapan standar tidak baku, ada beberapa tahapan proses tambahan, berupa: pemeraman/ penyimpanan buah kakao, depulperl 
pemerasan lendir (pulp kakao) yang yang baik pada biji kakao hasil dilakukan sebelum fermentasi dan fermentasi. Pemeraman buah kakao pencucian biji kakao setelah fermentasi. adalah cara yang paling mudah dilakukan Masing-masing perlakuan tersebut sehingga pemeraman buah kakao lebih bertujuan untuk mengurangi jumlah pulp banyak digunakan daripada proses kakao, dan akan memberikan pengaruh pemerasan lendir dan pencucian.

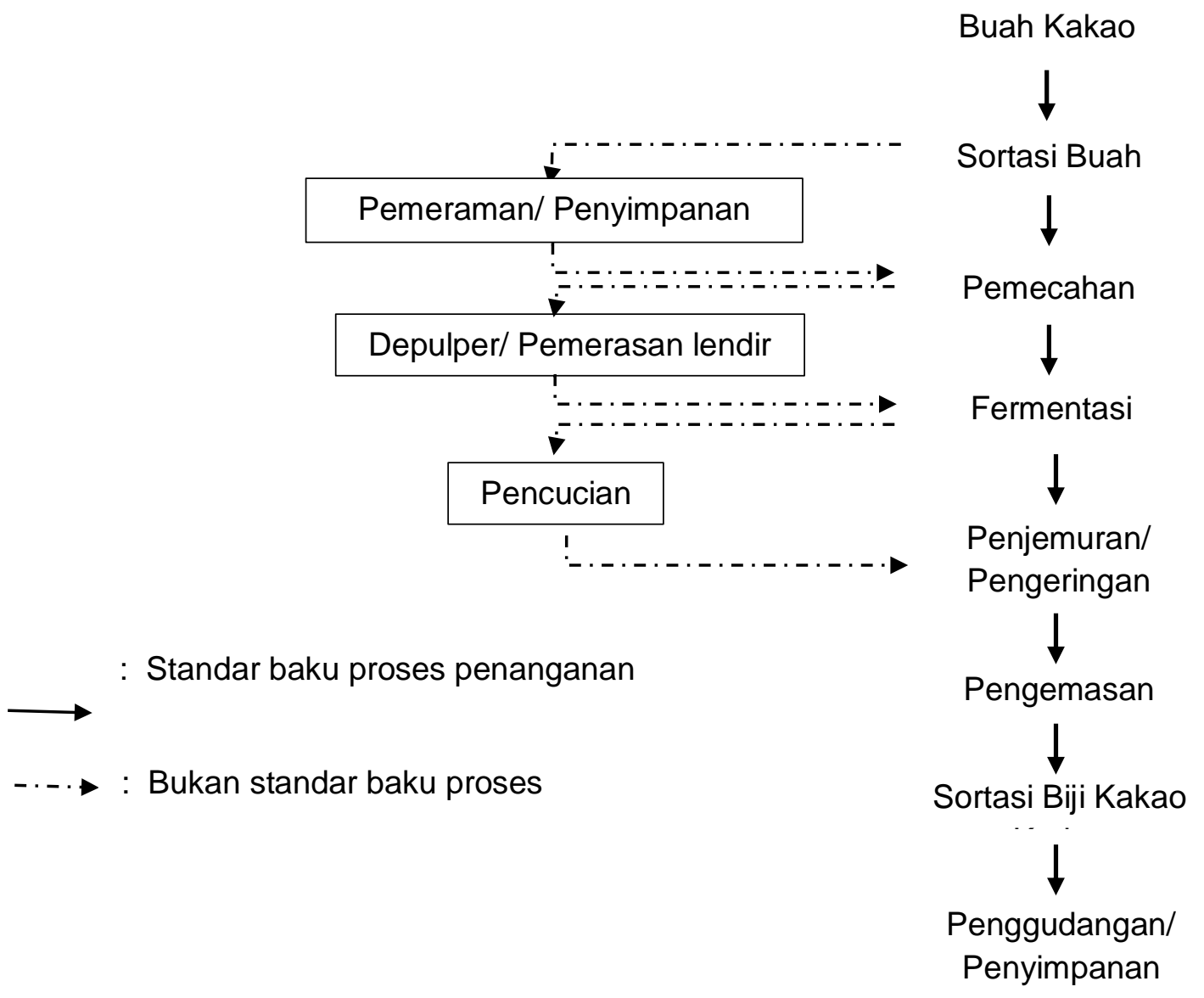

Gambar 1. Alur proses panen dan pascapanen kakao (Puslitkoka, 2010 di dalam Permentan No. 51, 2012). 
Faktor-faktor yang berpengaruh
Kakao Theobroma cacao
Genetik (varietas)

- Lokasi tumbuh

Kondisi iklim

- Kondisi tanah

Penyimpanan pod kakao Perlakuan pulp sebelum fermentasi (pulp preconditioning)

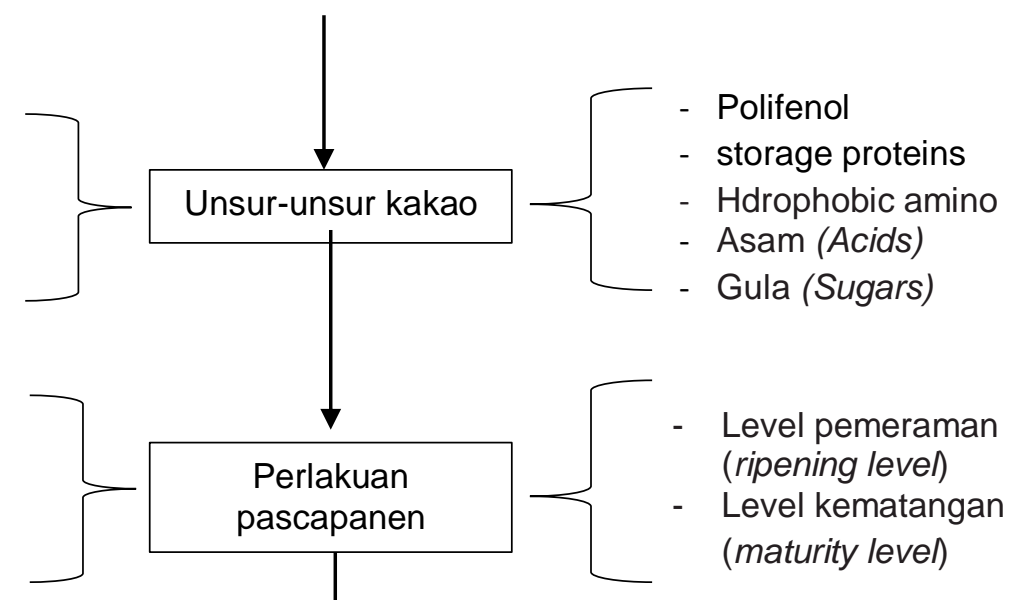

Metode yang digunakan

Durasi

Suhu

- Kondisi iklim

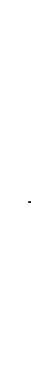

Faktor-faktor penentu 
tahapan perlakuan proses pemeraman buah kakao, fermentasi dan pengeringan biji kakao sangat dipengaruhi oleh jenis kakao, faktor lingkungan tumbuh tanaman, metode yang digunakan, lama perlakuan, kondisi iklim dan suhu perlakuan yang menjadi faktor penentu dari karakter dan pembentuk prekursor rasa kakao yang dihasilkan.

\section{Sortasi, pemeraman, dan pemecahan buah kakao}

Setelah panen selesai, sebaiknya dilakukan sortasi terhadap buah kakao yang akan diperam. Buah yang terlalu masak, terserang penyakit ataupun rusak tidak bisa diperam karena dapat menyebabkan buah busuk, dan mengontaminasi buah lainnya. Pemeraman buah kakao dapat dilakukan di kebun ataupun di dalam ruangan terbuka yang bersih dan terbuka agar buah kakao tidak mudah berjamur, Buah kakao yang berjamur masih bisa menghasilkan biji kakao yang baik, asalkan jamur dan kerusakan yang diakibatkan tidak sampai masuk ke bagian dalam polong buah dan merusak biji kakao (BPS, 2019; Siagian, 2017).

Penyimpanan buah (pod) kakao atau sering disebut pemeraman bertujuan untuk mengurangi kandungan pulp yang melapisi biji kakao basah. Pulp yang berlebihan dapat berpengaruh pada proses dan hasil fermentasi, salah satu nya dapat menyebabkan biji kakao mempunyai citarasa asam. Pemeraman buah kakao dapat mempercepat proses fermentasi, dikarenakan pada buah kakao yang telah diperam memiliki kadar air yang lebih rendah. Hasil penelitian menunjukkan bahwa penyimpanan pod dapat berpengaruh terhadap penurunan kandungan polifenol dan tingkat keasaman. Kandungan polifenol biji kakao menurun secara bertahap (<10\%) sebagai akibat dari proses fermentasi yang dilakukan selama enam hari setelah pemeraman tujuh hari (Afoakwa et al., 2012). Waktu pemeraman buah kakao memiliki pengaruh yang signifikan terhadap nilai kadar air dan kandungan bahan organik. Semakin lama waktu pemeraman buah kakao, semakin kecil kadar air dan semakin besar persentase bahan organik. Sedangkan lama pemeraman buah kakao tidak berpengaruh signifikan terhadap kadar abu biji kakao (Hartuti et al., 2019). Afoakwa et al., (2011) juga menyebutkan bahwa pemeraman buah kakao melebihi 5 hari diketahui mempengaruhi rasa dan kadar asam lemak bebas pada kakao. Pemeraman buah kakao juga berperan dalam pengurangan lapisan pulp, dan ikut berperan dalam pembentukan ruang kosong dalam tumpukan biji kakao, sehingga oksigen dapat masuk dalam tumpukan biji kakao selama proses fermentasi, serta mendorong terbentuknya aroma khas cokelat yang lebih baik (Loppies dan Yumas, 2008). Pemeraman buah kakao Malaysia juga dilakukan untuk mengurangi keasaman pada biji kakao selama proses fermentasi serta meningkatkan flavour biji kakao yang dihasilkan (Afoakwa et al., 2013: Afoakwa, 2016). Selain itu, penyimpanan buah kakao menunjukkan pengaruh yang sangat menguntungkan terhadap komposisi kimia biji kakao dan pengembangan flavour cokelat. Di Papua Nugini, pemeraman buah kakao selama 3-4 hari telah dianjurkan secara luas, karena dipertimbangkan membawa keuntungan pada proses fermentasi (SCPP-Swisscontact, 2013). Pemeraman buah kakao setelah panen dilakukan dengan cara meletakkan dan menumpuk buah pada ruang terbuka dengan suhu lingkungan selama 5-12 hari, tergantung kondisi kematangan buah dan lingkungan (Permentan No. 51, 2012). Hasil penelitian Hartuti et al., (2019) menyebutkan bahwa pemeraman buah kakao yang sehat dengan kondisi lingkungan pemeraman yang baik, menunjukkan bahwa buah kakao yang diperam selama 1-9 hari masih memiliki tampilan biji dan pulp kakao yang cukup baik.

Pemecahan buah kakao dilakukan setelah proses pemeraman. Pemecahan buah kakao biasanya dilakukan menggunakan kayu atau benda tumpul lainnya, agar buah tidak rusak. Bagi 
petani yang telah mahir, pemecahan buah dapat menggunakan pisau ataupun benda tajam lainnya, yang harus dilakukan dengan hati-hati agar tidak merusak keping biji. Setelah pemecahan buah kakao, biji kakao dilepaskan dari plasenta, dan disortasi kembali untuk memisahkan buah yang baik dengan buah yang rusak (SCPP-Swisscontact, 2013).

\section{Fermentasi biji kakao}

Fermentasi biji kakao merupakan salah satu faktor penting yang harus dilakukan untuk menghasilkan cokelat yang berkualitas tinggi. Keberhasilan proses tersebut, biasanya ditentukan dari perubahan suhu udara yang terjadi selama fermentasi serta adanya perubahan warna keping biji kakao dari ungu menjadi coklat setelah melalui proses fermentasi dan pengeringan (Hartuti et al., 2018). Fermentasi biji kakao bertujuan untuk membentuk citarasa khas cokelat (Ginting, 2011), keping biji berongga serta mengurangi rasa pahit dan sepat yang ada dalam biji kakao (Misnawi, 2008) sehingga menghasilkan biji dengan kualitas dan aroma yang baik, serta warna cokelat cerah dan bersih. Saat proses fermentasi, sebuah konsorsium alami terjadi, ragi, bakteri asam laktat, dan bakteri asam asetat bertanggung jawab untuk memproduksi alkohol dan asam. Kemudian mikroba metabolit menyebar ke dalam biji kakao dan terjadilah reaksi biokimia kompleks di dalam keping biji kakao. Fermentasi juga bertujuan untuk mematikan keping lembaga biji agar tidak tumbuh sehingga perubahan-perubahan di dalam biji mudah terjadi. Perubahan-perubahan fisik dan kimia terjadi pada keping biji kakao secara enzimatis yang berkelanjutan sampai tahap pengeringan. Perubahanperubahan enzimatis memungkinkan terbentuknya senyawa prekursor aroma dan citarasa khas kakao. Misnawi (2008) juga menyebutkan bahwa senyawasenyawa calon pembentuk citarasa khas cokelat seperti asam-asam amino bebas dan peptida-peptida tertentu serta gula pereduksi akan terbentuk selama proses fermentasi berlangsung. Senyawasenyawa tersebut dihasilkan melalui degradasi secara enzimatik senyawa protein dan karbohidrat biji kakao. Sejalan dengan pembentukan senyawa-senyawa calon pembentuk ciatarasa khas cokelat, proses fermentasi mengurangi pengaruh negatif polifenol dengan adanya oksidasi dan eksudasi keluar biji sehingga konsentrasinya berada pada aras yang berimbang dan diterima sebagai citarasa keseluruhan cokelat yang unik dan menarik.

Lama fermentasi biji kakao optimal yaitu 4-5 hari (4 hari bila udara lembab dan 5 hari bila udara terang) (Permentan No. 51, 2012). Biasanya, lama proses fermentasi dipengaruhi oleh jenis kakao dan berbagai faktor lainnya seperti metode fermentasi yang digunakan, serta jumlah biji kakao yang difermentasi. Secara umum proses fermentasi dilakukan selama 5-7 hari (SCPPSwisscontact, 2013), proses fermentasi yang terlalu singkat atau kurang dari waktu yang diperlukan akan menghasilkan biji yang dominan masih berwarna ungu (atau biji slaty yaitu biji berwarna hitam dan keras atau pejal), pahit dan sepat yang berlebihan pada produk akhir yang dihasilkan. Sedangkan fermentasi yang berlebihan akan menghasilkan biji kakao yang berwarna cokelat gelap, kurang cita rasa cokelat, berbau tidak enak, serta terjadi pertumbuhan kapang pada kulit luar biji kakao (SCPP-Swisscontact, 2013). Lama fermentasi berpengaruh sangat nyata terhadap kadar air, kadar abu, kadar lemak dan nilai organoleptik (aroma, warna dan rasa) dan tidak berpengaruh terhadap daya larut dalam air pada bubuk kakao yang dihasilkan (Ginting, 2011).

Salah satu alat fermentasi kakao yang selama ini banyak diadopsi di Indonesia adalah kotak fermentasi bertingkat (Gambar 2). Keunggulan yang dimiliki alat ini, antara lain: perawatan mudah dan murah, hasil fermentasi baik, suhu fermentasi tercapai, lapisan lendir terurai dan terlepas dari permukaan biji secara alami, terjadi perubahan nilai $\mathrm{pH}$ 
biji karena pembentukan senyawasenyawa asam (Permentan No. 51, 2012). Kelemahan kotak fermentasi bertingkat adalah ketika volume biji kakao yang akan difermentasi sangat sedikit, maka kenaikan suhu atau panas rendah dan mengakibatkan timbulnya jamur pada biji kakao. Selain kotak fermentasi, sebagian petani kakao masih ada yang menggunakan media lainnya dalam proses fermentasi biji kakao, seperti keranjang bambu, ember plastik, karung plastik, dan lain-lain, sebagaimana ditunjukkan pada Gambar 2. SCPPSwisscontact (2013) menyebutkan bahwa; banyak petani kakao Indonesia yang melakukan proses fermentasi dengan menggunakan karung plastik, selain murah, karung plastik juga mudah didapat. Setelah biji kakao dimasukkan dalam karung plastik, kemudian diletakkan di atas kayu balok sebagai alasnya.

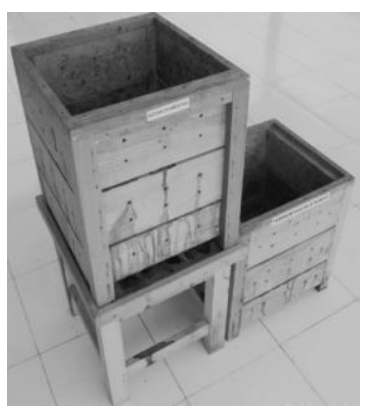

Kotak fermentasi biji kakao bertingkat

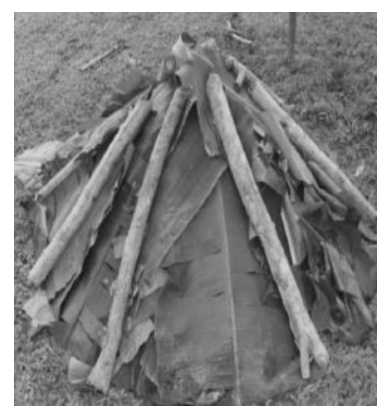

Fermentasi tumpukan biji kakao ditutup dengan daun pisang

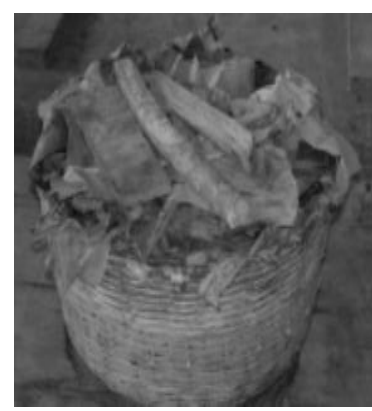

Fermentasi biji kakao menggunakan keranjang yang ditutup daun pisang

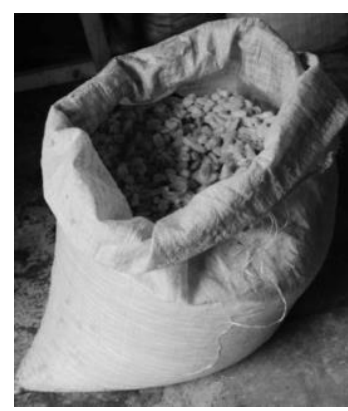

Fermentasi biji kakao menggunakan karung goni/ karung plastik

Gambar 2. Alat fermentasi Kakao (SCPP-Swisscontact, 2013; Afoakwa, 2016)

Fermentasi kakao yang telah selesai biasanya ditandai dengan pulp mudah dibersihkan dari kulit biji, biji kakao sudah kering dan lembab, kulit biji berwarna coklat, beraroma asam cuka, dan apabila dilakukan pemotongan arah melintang (cut test) akan tampak cincin berwarna coklat pada kakao jenis mulia
(Criollo) dan sudah tidak akan tampak warna ungu pada kakao jenis lindak (Forastero), sebagaimana ditunjukkan pada Gambar 3. Biji-biji kakao yang belum cukup mengalami fermentasi warna pulpnya putih, kulit biji belum berwarna coklat dan beraroma alkohol.

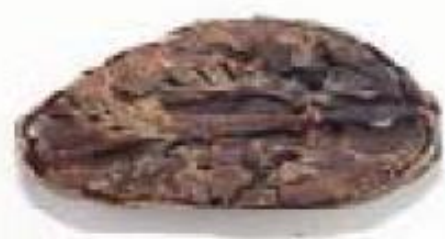

Well fermented

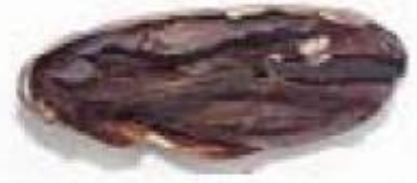

Slightly over fermented
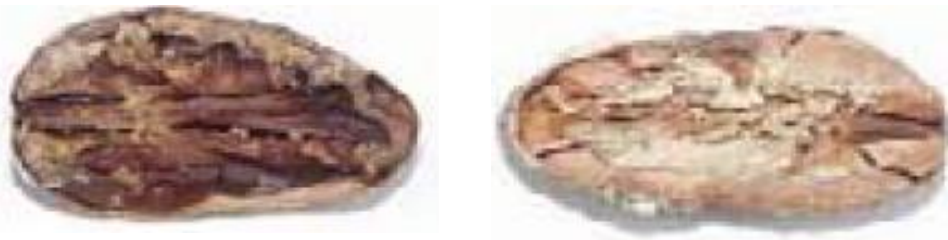

Well fermented (Pale) 


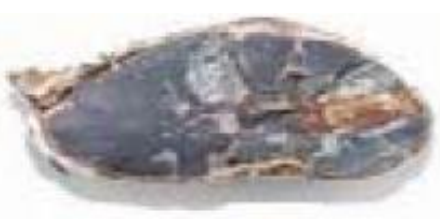

Slaty and unfermented

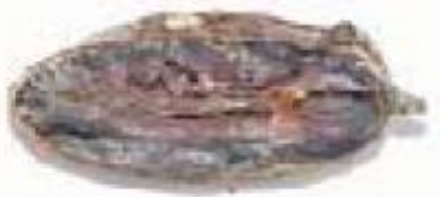

Violet
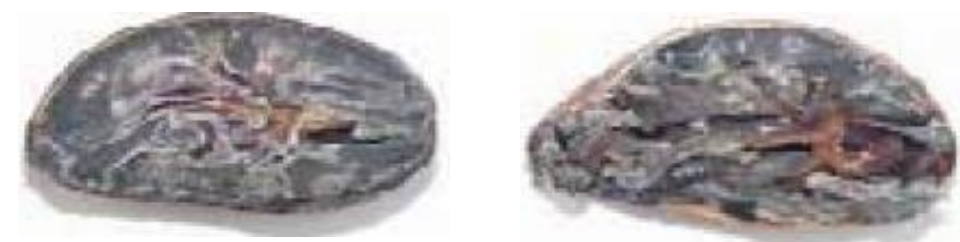

Stay turning violet

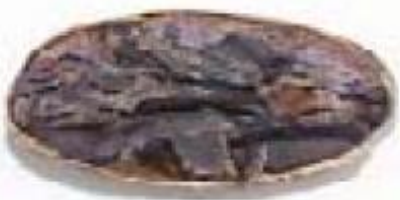

Violet turning brown
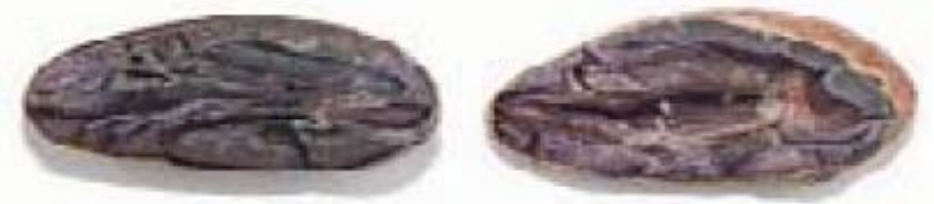

Partly purple and partly brown

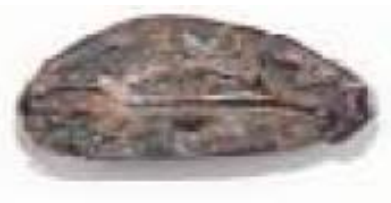

Mouldy
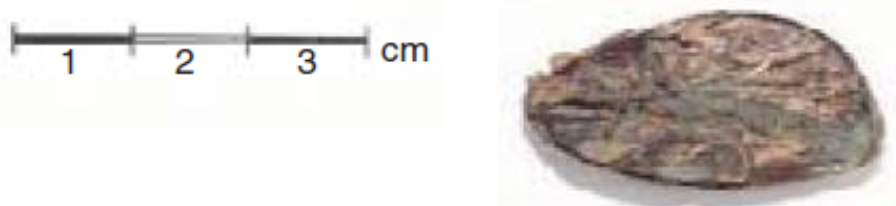

Mouldy and infested

Gambar 3. Kualitas biji kakao berdasarkan uji belah (Afoakwa, 2016)

\section{Pengeringan biji kakao}

Kualitas biji kakao juga sangat dipengaruhi oleh perubahan kimiawi dan biokimiawi yang kompleks pada biji kakao selama proses fermentasi dan pengeringan (Afoakwa et al., 2012). Bahkan proses fermentasi dan pengeringan secara nyata dapat meningkatkan prekursor rasa biji kakao (Misnawi, 2008), dan menentukan karakteristik kualitas biji kakao dalam industri cokelat (Barrientos et al., 2019). Selama proses pengeringan terjadi peningkatan dan pengembangan rasa cokelat, mengurangi rasa pahit dan sepat serta pengembangan warna coklat dari biji kakao yang difermentasi dengan baik (Afoakwa, 2016).

Pengeringan biji kakao bertujuan untuk menurunkan kadar air biji kakao dari $60 \%$ sampai pada kondisi dimana kandungan air dalam biji tidak dapat menurunkan mutu biji dan biji, tidak dapat ditumbuhi cendawan. Pengeringan setelah proses fermentasi dilakukan hingga biji kakao memiliki kadar air $\leq$ $7,5 \%$. Pengeringan biji kakao dapat dilakukan dengan bantuan sinar matahari, ataupun menggunakan alat pengering buatan. Pengeringan dengan sinar matahari, sangat tergantung pada kondisi cuaca. Faktor cuaca yang tidak menentu turut memberikan pengaruh terhadap kualitas biji kakao. Jika cuaca tidak memungkinkan (misalnya saat musim hujan), pengeringan dapat dilakukan dengan alat pengering buatan. Pengeringan biji kakao dapat dilakukan dengan penjemuran menggunakan panas matahari, memakai alat pengering, atau kombinasi keduanya. Pengeringan menggunakan cahaya matahari biasanya dilakukan selama 5-8 hari jika cuaca cerah (Afoakwa, 2016; Baihaqi et al., 
2016; SCPP-Swisscontact, 2013). Namun pada musim hujan pengeringan bisa lebih dari 2 minggu. Sementara itu, pengeringan menggunakan alat pengering mekanis sangat dipengaruhi oleh suhu udara panas, laju udara pengering dan ketebalan tumpukan biji. Pada proses pengeringan biji kakao menggunakan pengering kabinet dengan suhu pengering $50{ }^{\circ} \mathrm{C}$ selama 24 jam, diperoleh kadar air biji kakao 6-9\% (Hartuti et al., 2018). Sementara itu, kombinasi pengeringan menggunakan sinar matahari dan menggunakan alat mekanis juga diterapkan pada perkebunan besar (SCPP-Swisscontact, 2013).

Suhu pengeringan berpengaruh terhadap kadar lemak, keasaman, dan kadar asam amino bebas. Semakin tinggi suhu pengeringan kadar lemak semakin rendah, namun kadar keasaman dan asam amino bebas semakin meningkat. Apabila biji dikeringkan terlalu cepat, akan berpengaruh terhadap bau asam yang tajam dan sebaliknya jika terlalu lambat maka jamur akan tumbuh pada biji kakao (Indarti, 2007). Peningkatan suhu pengeringan akan meningkatkan rasa kelat dan asam sehingga suhu pengeringan tidak lebih dari 65-70 ${ }^{\circ} \mathrm{C}$ (SCPP-Swisscontact, 2013). Beberapa cara dapat dilakukan untuk mengetahui selesainya pengeringan biji kakao, antara lain: berdasarkan penurunan berat biji yaitu apabila berat biji kering mencapai $1 / 3$ dari berat basah; dan berdasarkan kekerasan biji, pada umumnya biji kakao yang sudah cukup kering mudah patah atau rapuh, bila digenggam, kemudian dilepas dengan posisi tangan terbalik, maka semua biji akan jatuh (tidak lengket/ menempel di tangan) dan terasa bunyi seperti kacang; serta dapat juga menggunakan alat pengukur kadar air digital (SCPP-Swisscontact, 2013).

\section{Sortasi, pengemasan, penggudangan biji kakao}

Sortasi biji kakao kering dilakukan untuk mengelompokkan biji kakao berdasarkan ukuran, memisahkan antara biji kakao dengan kotoran dan benda asing, bahkan dengan kakao yang bermutu kurang baik, misalnya biji dempet, biji pipih untuk mendapatkan mutu biji kakao yang seragam sebelum pengemasan dan penyimpanan (Permentan No. 51, 2012). Biji kakao yang bercampur dengan bukan biji (plasenta, pecahan kulit, batu/kerikil, benda asing lainnya) akan menurunkan nilai mutu terhadap biji kakao (SCPPSwisscontact, 2013).

Pengemasan biji kakao dilakukan dengan tujuan untuk menyimpan, mempertahankan dan melindungi biji kakao kering dari gangguan serangga dan gangguan faktor lingkungan, sebelum dilakukan tahapan pengolahan selanjutnya. Umumnya biji kakao yang telah disortir dan bebas dari kotoran dikemas dalam karung bersih dan disimpan dalam gudang. Kemasan merupakan wadah penyimpanan suatu bahan dengan beberapa persyaratan, antara lain: dapat mempertahankan mutu produk supaya tetap bersih serta mampu memberi perlindungan dari kotoran, pencemaran, dan kerusakan fisik, serta kerusakan kimia lainnya. Dalam pengemasan dan penyimpanan biji kakao yang harus diperhatikan, antara lain: biji yang telah disortasi kemudian dikemas dalam karung dengan berat bersih per karung $60 \mathrm{~kg}$. Setiap karung diberi label yang menunjukkan nama komoditi, jenis mutu dan identitas produsen kemudian biji kakao disimpan di ruangan yang bersih, kelembaban tidak melebihi $75 \%$, ventilasi cukup, dan tidak dicampur dengan produk pertanian lainnya yang berbau keras karena biji kakao dapat menyerap bau-bauan (Permentan No. 51, 2012). Selain itu, pengemasan serta penyimpanan biji kakao, harus menggunakan karung yang bersih, bukan bekas pestisida ataupun pupuk, memiliki pori-pori untuk keluar masuk udara dan mencegah kelembaban yang tinggi serta kontaminasi (Ariyanti, 2017). 


\section{UPAYA PENINGKATAN KUALITAS BIJI KAKAO MELALUI PENANGANAN PASCAPANEN}

Penanganan pascapanen biji
kakao yang baik dan benar perlu
dilakukan sesuai pedoman yang dianjurkan (Permentan No. 51, 2012), dan merupakan salah satu upaya yang dapat dilakukan untuk menanggulangi permasalahan rendahnya kualitas biji kakao. Sebagaimana diketahui bahwa rendahnya kualitas biji kakao Indonesia umumnya disebabkan penerapan proses penanganan pascapanen yang kurang baik dengan berbagai alasan. Oleh karena itu, untuk meningkatkan kualitas biji kakao Indonesia penerapan proses dan penanganan pascapanen kakao harus dilakukan. Pemeraman buah kakao, fermentasi dan pengeringan merupakan proses penting yang harus dilakukan karena dapat meningkatkan citarasa kakao yang dihasilkan, sebagaimana disebutkan pada Tabel 3 . Berdasarkan tahapan penanganan pascapanen kakao, diketahui bahwa fermentasi biji kakao merupakan proses yang penting dan agak sulit dilakukan. Keberhasilan proses fermentasi juga sangat dipengaruhi oleh berbagai faktor, diantaranya adalah ketersediaan jumlah biji kakao, waktu/durasi fermentasi, alat fermentasi, metode fermentasi dan serta kondisi berbagai faktor selama proses fermentasi seperti aerasi dan suhu fermentasi.

Saat ini, berbagai upaya peningkatan kualitas biji kakao melalui perlakuan fermentasi terus ditingkatkan. Bahkan beberapa peneliti menyebutkan bahwa biji kakao kering tanpa fermentasi dapat ditingkatkan kualitasnya dengan cara melakukan fermentasi ulang atau refermentasi. Biji kakao kering jemur tanpa fermentasi dapat ditingkatkan kualitasnya melalui proses fermentasi dengan berbagai perlakuan khusus, seperti: merendam biji kakao selama 2-3 jam, lalu diberi tambahan substrat (Mulyawanti dan Hidayat, 2018), memberikan tambahan inokulum (Apriyanto et al., 2017) memberikan perlakuan pendahuluan dan diinkubasi dalam medium buffer asetat (Atmaja, 2016). Perbaikan mutu biji kakao kering jemur, yang kemudian difermentasi dengan perlakuan khusus dapat diketahui berdasarkan perubahan kimia pada biji (Atmaja, 2016; Apriyanto et al., 2017: Apriyanto et al., 2020) sehingga apabila fermentasi tidak dapat dilakukan oleh petani kakao, maka salah satu strategi yang dapat ditempuh adalah dengan melakukan fermentasi biji kakao yang telah dikeringkan pada tingkat pengumpul, distributor, dan seterusnya.

Tabel 3. Tujuan perlakuan dan penanganan pascapanen biji kakao

\begin{tabular}{|c|c|}
\hline Perlakuan & Tujuan \\
\hline $\begin{array}{l}\text { Pemeraman } \\
\text { buah kakao }\end{array}$ & $\begin{array}{l}\text { Mengurangi lapisan pulp dan membentu } \\
\text { ruang kosong dalam tumpukan biji kaka } \\
\text { sehingga oksigen dapat masuk dalam } \\
\text { tumpukan biji selama fermentasi. } \\
\text { Mempercepat proses fermentasi, } \\
\text { mendorong terbentuknya aroma khas } \\
\text { cokelat, menurunkan kadar air, polifenol } \\
\text { keasaman, serta mempengaruhi kualitas } \\
\text { fermentasi dan penampilan biji. }\end{array}$ \\
\hline Fermentasi & $\begin{array}{l}\text { Menghasilkan senyawa-senyawa calon } \\
\text { pembentuk citarasa khas cokelat dan } \\
\text { mempengaruhi kualitas dan penampilan } \\
\text { biji kakao }\end{array}$ \\
\hline
\end{tabular}
Referensi

Loppies dan Yumas (2008); Afoakwa et al. (2012); Afoakwa (2016); Hartuti (2019)

Misnawi (2008); Ginting (2011); Misnawi (2008); Towaha et al. (2012); Afoakwa (2016)

Permentan No. 51, 
mempercepat proses pengeringan, memperbaiki penampakan biji dan mengurangi kadar kulit.

Pengeringan

Sortasi

Pengemasan

Penyimpanan

dan penggudangan
Menurunkan kadar air biji kakao, membentuk citarasa kakao, serta menentukan karakteristik kualitas kakao dalam industri cokelat

Memisahkan biji kakao dengan kotoran dan benda asing, bahkan dengan kakao yang bermutu kurang baik

Melindungi biji kakao, memudahkan dalam pendistribusian dan penyimpanan biji kakao.

Mengendalikan mutu biji kakao dan melindungi biji kakao dari hama dan kerusakan
Jinap dan Thien

(1994); Misnawi (2008); Barrientos et al. (2019).

Permentan No. 51

(2012);

SCPP-Swisscontact

(2013)

Permentan No. 51

(2012);

Sumantri et al., 2016

SCPP-Swisscontact

(2013)

\section{SIMPULAN}

Penanganan pascapanen kakao yang baik yang mengacu pada Permentan No. 51 Tahun 2012 perlu diupayakan secara intensif untuk meningkatkan kualitas, daya saing dan nilai jual biji kakao yang dihasilkan. Pemeraman buah kakao, proses fermentasi, dan pengeringan biji kakao merupakan tahapan penanganan pascapanen biji kakao yang memiliki peran penting pada peningkatan kualitas biji kakao. Pemeraman buah kakao bertujuan mempercepat proses fermentasi, mendorong terbentuknya aroma khas cokelat yang baik, dan mempengaruhi kualitas dan tampilan biji kakao fermentasi. Proses fermentasi biji kakao bertujuan untuk menghasilkan senyawa-senyawa calon pembentuk citarasa khas cokelat seperti asam-asam amino bebas dan peptida-peptida tertentu serta gula pereduksi, dan mempengaruhi mutu dan penampilan biji kakao. Selanjutnya, pengeringan biji kakao bertujuan untuk menurunkan kadar air biji kakao dan membentuk citarasa cokelat, dan mengurangi rasa sepat dan pahit.

\section{DAFTAR PUSTAKA}

1. Afoakwa, E. O., Jennifer, Q., Agnes, S. B., Jemmy, S. T. and Firibu, K. S. 2012. "Influence of Pulp-Preconditioning and Fermentation on Fermentative Quality and Appearance of Ghanaian Cocoa (Theobroma Cacao) Beans" International Food Research Journal 19 (1): 127-33.

2. Afoakwa, E. O., Kongor, J. E., Takrama, J. and Budu, A. S. 2013. "Changes in Nib Acidification and Biochemical Composition during Fermentation of Pulp Pre-Conditioned Cocoa (Theobroma Cacao) Beans" International Food Research Journal 20 (4): 1843-53.

3. Afoakwa, E. O. 2016. Chocolate Science and Technology. Second Edition. United Kingdom: Wiley Blackwell.

4. Afoakwa, E. O, Jennifer Q, Jemmy T., and Agnes S. B. 2011. "Chemical Composition and Physical Quality Characteristics of Ghanaian Cocoa Beans as Affected by Pulp PreConditioning and Fermentation," ICCO 2009. https://doi.org/10.1007/s13197011-0446-5.

5. Apriyanto, M., Sutardi, Supriyanto, dan 
Harmayani, E. 2017. "Fermentasi Biji Kakao Kering Menggunakan Saccharomyces Cerevisiae, Lactobacillus Lactis, Dan Acetobacter Aceti." Agritech $37 \quad$ (3) https://doi.org/http://doi.org/10.22146/agri tech.17113.

6. Apriyanto, M., Mardesci, H., dan Rujiah. 2020. "Perubahan Asam Asetat, Total Polifenol dan Warna Biji Kakao Asalan Selama Fermentasi." Jurnal Industri Hasil Perkebunan Vol..15 No. 1, Juni 2020: 10 16

7. Ariyanti, M. 2017. Karakteristik Mutu Biji Kakao (Theobroma Cacao L) dengan Perlakuan Waktu Fermentasi Berdasar SNI 2323:2008. Jurnal Industri Hasil Perkebunan Vol. 12 No. 1 Juni 2017: 3442

8. Atmaja, M. I. P., Haryadi dan Supriyanto; 2016. "Peningkatan Kualitas Biji Kakao Non Fermentasi Melalui Quality Improvement of Non Fermented Cocoa Bean Through Pre-Incubation." Jurnal Tanaman Indutri Dan Penyegar (J.TIDP) 3(1) (maret 2016): 11-19.

9. Baihaqi, Hayati R., dan Abubakar, Y. 2016. "Pengaruh Fasilitator Fermentasi Dan Suhu Pengeringan Terhadap Kualitas Biji Kakao." Jurnal Floratek 11 (2): 134-42.

10. Barrientos, Luis Danilo Porras, Juan Diego, Torres Oquendo, Maritza Andrea, Gil Garzón, Olga Lucia, and Martínez Álvarez. 2019. "Effect of the Solar Drying Process on the Sensory and Chemical Quality of Cocoa ( Theobroma Cacao L .) Cultivated in Antioquia, Colombia." Food Research International 115 (52): 259-67. https://doi.org/10.1016/j.foodres.2018.08. 084.

11. BPS. 2019. "Statistik Kakao Indonesia 2018." Indonesia.

12. Davit, J.M; Yusuf, RP; dan Yudari, D.A.S. 2013. "Pengaruh Cara Pengolahan Kakao Fermentasi dan Non Fermentasi Terhadap Kualitas, Harga Jual Produk Pada Unit Usaha Produktif (UUP) Tunjung Sari , Kabupaten Tabanan" 2 (4): 191-203.

13. Departemen Perindustrian. 2007. Gambaran Sekilas Industri Kakao.

14. Ginting, S; 2011. "Mempelajari Pengaruh Lama Fermentasi dan Lama Penyangraian Biji Kakao Terhadap Mutu Bubuk Kakao." STEVIA I (No. 1-Januari 2011): 6-11.

15. Hartuti, S., Bintoro, N., Karyadi, J.N.W., dan Pranoto, Y. 2018. Fermentasi Isothermal Biji Kakao (Theobroma cacao. L) dengan Sistem Aerasi Terkendali. Agritech, 38 (4) 2018, 364-374. DOI: http://doi.org/10.22146/agritech.32162

16. Hartuti, S., Bintoro, N., Karyadi, J.N.W., dan Pranoto, Y. 2019. "Pengaruh Pemeraman Buah Kakao Terhadap Kadar Air, Kadar Abu, dan Bahan Organik Pada Biji Kakao." In Prosiding Seminar Nasional "Inovasi Teknologi Untuk Masyarakat." Banda Aceh, Indonesia.

17. Hatmi, R.U. dan Rustijarno, S. 2012. Teknologi Pengolahan Biji Kakao Menuju SNI Biji Kakao 01-2323-2008. BPTP Yogyakarta: Balai Pengkajian Teknologi Pertanian Yogyakarta, , Indonesia.

18. Herawati, R. A., dan Tinaprila, N. 2015. "Kinerja Dan Efisiensi Rantai Pasok Biji Kakao Di Kabupaten Pasaman, Sumatera Barat." Jurnal Tanaman Industri Dan Penyegar 2 (1): 43-50.

19. Hernani dan Haliza, W; 2013. "Optimasi Komposisi Nutrien Untuk Pembentukan Komponen Citarasa Pada Fermentasi Biji Kakao Asalan." Jurnal Pascapanen 10(2): 74-82.

20. Indarti, E. 2007. "Efek Pemanasan Terhadap Rendemen Lemak Pada Proses Pengepresan Biji Kakao Eti Indarti." Jurnal Rekayasa Kimia Dan Lingkungan 6 (2): 50-54.

21. Jinap, S, and J Thien. 1994. "Effect of Drying on Acidity and Volatile Fatty Acids Content of Cocoa Beans." Jurnal Sci Food Agric 65: 67-75.

22. Kongor, J. E., Hinneh, M., Walle, D. V. D., Afoakwa, E. M., Boeckx, P., and Dewettinck, K. 2016. "Factors Lnfluencing Quality Variation in Cocoa (Theobroma Cacao) Bean Flavour Profile - A Review." Food Research International 82: 44-52. https://doi.org/10.1016/j.foodres.2016.01. 012.

23. Krähmer, Andrea, Annika Engel, Daniel Kadow, Naailah Ali, Pathmanathan Umaharan, Lothar W. Kroh, and Hartwig S. 2015. "Fast and Neat - Determination of Biochemical Quality Parameters in Cocoa Using near Infrared Spectroscopy." Food Chemistry 181: 152-59. https://doi.org/10.1016/j.foodchem.2015. 02.084.

24. Loppies, J. E; \& Yumas, M; 2008. "Mempelajari Proses Fermentasi Biji 
Kakao dengan Penambahan Aktivator." Jurnal Industri Hasil Perkebunan Vol. 3, No: 25-32.

25. Listyati, D., Wahyudi A., dan Hasibuan A.M. 2014. "Penguatan Kelembagaan untuk Peningkatan Posisi Tawar Petani dalam Sistem Pemasaran Kakao" J. TIDP 1(1), 15-28.

26. Manalu, R. 2018. "Processing of Smallholder Plantations Cocoa Production to Increase Farmers Income." Jurnal Ekonomi Dan Kebijakan Publik 9 (2): 99-111.

27. Misnawi. 2008. "Perubahan Fisiko-Kimia Selama Fermentasi Biji Kakao" 24 (1): 53-70.

28. Mulyawanti I. T,. \& Hidayat R. 2018. "Pengaruh Jenis Fermentor Terhadap Mutu Biji Kakao Kering Non Fermentasi." Jurnal Penelitian Pascapanen Pertanian 15 (2): 91-98.

29. Munarso, S. J. 2016. "Postharvest Handling to Increase Cocoa Bean Quality and Its Competitiveness". Doi.org/10.21082/jp3.v35n3.2016.p111120.

30. Nurhayati, R. R. Utami, dan Yusdianto. 2016. "Teknologi Digital Sensor Warna Untuk Mengukur Tingkat Fermentasi Kakao (Ulasan)." Jurnal Industri Hasil Perkebunan 1 (2016), 16-23.

31. Permentan No. 51. 2012. "Peraturan Menteri Pertanian Nomor 51/Permentan/Ot.140/9/2012." Jakarta, Indonesia: Menteri Hukum dan HAM Republik Indonesia.

32. SCPP-Swisscontact. 2013. Pasca Panen, Kualitas Biji Kakao \& Fermentasi. Edited by SCPP-Swisscontact. Medan, Indonesia.

33. Siagian, V. J.; 2017. Outlook Kakao 2017. Indonesia: Pusat Data dan Sistem Informasi Pertanian Kementerian Pertanian, Sekretariat Jenderal Kementerian Pertanian, Indonesia.
34. SNI-Standar Nasional Indonesia 012323:2008 Biji Kakao. Badan Standardisasi Nasional. Jakarta.

35. SNI-Standar Nasional Indonesia 012323:2008/Amd-2010. Biji KakaoAmandemen 1. Badan Standardisasi Nasional. Jakarta.

36. Sudjarmoko, B., Listyati D., danbb Hasibuan A. M,. 2017. "Analisis Penyusunan Prioritas Kegiatan dalam Mendukung Diberlakukannya Kewajiban Fermentasi Biji Kakao." Jurnal Tanaman Industri Dan Penyegar (JTIDP) 4, No. 3 (November): 153-62.

37. Sumanto, Efendi, D.S., \& Prastowo, B. 2015. "Peningkatan Mutu Melalui Teknologi Bioproses Pemerasan Pulp (Depulping) Biji Kakao Secara Mekanis." Jurnal Tanaman Industri Dan Penyegar (JTIDP) 2 (2): 77-84.

38. Sumantri, Hastuty, S. S., dan Fitriani. 2016. Penangan Pascapanen Kakao di Desa Tarobok Kecamatan Baebunta Kabupaten Luwu Utara. Jurnal Perbal, Vol. 4 (2). Juni 2016.

39. Towaha J., Anggraini D. A., dan Rubiyo. 2012 Keragaan Mutu Biji Kakao dan Produk Turunannya pada Berbagai Tingkat Fermentasi: Studi kasus di Tabanan, Bali PELITA PERKEBUNAN, Volume 28, Nomor 3, Edisi Desember 2012.

40. Widyastutik dan Arianti R. K,. 2013. "Strategi Kebijakan Mutu dan Standar Produk Ekspor dalam Meningkatkan Daya Saing (Studi Kasus Produk Ekspor Biji Kakao)" Jurnal Manajemen dan Agribisnis, Vol.10 (2): 98-108. 